\title{
Potency and hourly
} maintenance requirement of combinations of mivacurium and pancuronium in adults

Pekka Rautoma MD PhD, Olli Erkola $\mathrm{MD} \mathrm{PhD}$, Olli A. Meretoja MD PhD*

Purpose: To evaluate the dose-response and maintenance requirements of a combination of mivacurium and pancuronium (CMP) in clinical practice.

Methods: In a randomised, open clinical study, 70 patients, 17-50 yr of age, were anaesthetised with propofol, alfentanil and nitrous oxide in oxygen. Thirty patients received mivacunium and 20 patients received pancuronium to establish dose-response curves for these agents. Hourly maintenance requirements of mivacurium and pancuronium to maintain 90-95\% neuromuscular blockade (NMB) were determined. Thereafter, 20 additional patients received CMP in incremental doses to establish a cumulative dose-response curve for CMP followed by maintenance doses of CMP. NMB was recorded by adductor pollicis electromyography.

Results: The $\mathrm{ED}_{95}$ values for mivacurium and pancuronium were 100 and $66 \mu \mathrm{g} \cdot \mathrm{kg}^{-1}$, respectively; and for the CMP 2:1 (in $\mathrm{mg}: \mathrm{mg}$ basis), $32 \mu \mathrm{gg}^{-1}$ mivacurium together with $16 \mu \mathrm{g} \cdot \mathrm{kg}^{-1}$ pancuronium. This CMP was 1.8 times more potent than one parent agent $(P<0.0001)$. When CMP 2:1 was used, $60 \%$ of normal maintenance requirement of pancuronium reduced the requirement of mivacunium by $>90 \%$. If cMP $20: 1$ was used, then $20 \%$ of normal maintenance requirement of pancuronium reduced the requirement of mivacurium by $>70 \%$. Neostigmine $35 \mu \mathrm{g} \cdot \mathrm{kg}^{-1}$ given at $T_{\text {, }}$ $10 \%$ recovery following CMP reversed the NMB to a TOF ratio of 0.70 in $9.5 \pm 3.9 \mathrm{~min}$.

Conclusion: These results reflect considerable synergism between mivacurium and pancuronium. The CMP is near intermediate-acting and the NMB is easily reversed with neostigmine. By using CMP, it may be possible to save some pharmacological costs during maintenance of anaesthesia.

Objectif : Évaluer les besoins dose-réponse de même que les besoins d'entretien d'un mélange mivacurium et pancuronium (CMP) en pratique clinique.

Méthodes : Dans une étude clinique ouverte et aléatoire, 70 patients âgés de 17 à 50 ans ont été anesthésiés avec propofol, affentanil, $\mathrm{N}_{2} \mathrm{O}$ et $\mathrm{O}_{2}$. Trente patients ont reçu du mivacurium et 20 patients ont reçu du pancuronium pour construire des courbes dose-réponse pour les deux médicaments. On a ensuite déterminé les besoins horaires de mivacurium et de pancuronium pour maintenir un bloc neuro-musculare (BNM) à 90-95\%. Par la suite, 20 patients supplémentaires ont reçu le CMP en doses croissantes pour établir une courbe dose-réponse cumulative pour le CMP, suivi de doses de maintien de CMP. Le bloc a été enregistré par électromyographie de l'adducteur du pouce.

Résultats : Les valeurs $\mathrm{ED}_{95}$ pour le mivacurium et le pancuronium ont été respectivement de 100 et $66 \mu \mathrm{g} \cdot \mathrm{kg}^{-1}$; et pour le mélange CMP, en rapport 2:I sur la base de mg:mg, $32 \mu \mathrm{g}^{\mathrm{kg}} \mathrm{g}^{-1}$ pour le mivacunium et $16 \mu \mathrm{g}^{-1} \cdot \mathrm{kg}$ pour le pancuronium. Cette combinaison CMP a été $I, 8$ fois plus puissante que chacun des agents constituants $(P<0,000 I)$. Lorsqu'on a utilisé le CMP 2:1, 60\% de la dose d'entretien normale de pancuronium a réduit les besoins de mivacunium de $>90 \%$. Si on utilisart un mélange CMP 20:1, 20\% de la dose de maintien normale de pancuronium réduisait les besoins de mivacurium de $>70 \%$. La néostigmine $35 \mu \mathrm{g} \cdot \mathrm{kg}^{-1}$ administrée lorsque le bloc produit par cMP avait récupéré à une valeur $T_{1}=10 \%$ entrainait une récupération du BNM évalué par le train-de-quatre de 0,70 en $9.5 \pm 3.9$ min.

Conclusion : Ces résultats indiquent une synergie considérable entre le mivacurium et le pancuronium. Le mélange CMP se comporte presque comme un relaxant musculaire de durée intermédiaire dont le bloc est facilement antagonisé par la néostigmine. Par l'utilisation du CMP, il est possible de faire des économies quant aux coûts des médicaments durant le maintien de l'anesthésie.

From the Department of Anaesthesia, Maria Hospital of Helsinki City Hospital, Helsinki, and Children's Hospital, ${ }^{*}$ University of Helsinki, Helsinki, Finland.

Address for correspondence: P. Rautoma, MD PhD, Department of Anaesthesia, Maria Hospital, Lapinlahdenkatu 16, 00180 Helsinki, Finland; Fax: 358-9-31063378.

Accepted for publication December 21, 1997. 
$\mathrm{P}$ ANCURONIUM is a commonly used longacting non-depolarising neuromuscular blocking agent (NMBA). It is often chosen when neuromuscular blockade (NMB) is needed for a relatively long time even though its use is frequently associated with considerable postoperative residual curarisation. ${ }^{1,2}$ Mivacurium is the shortest-acting NMBA currently available. Its use is not associated with residual curarisation and NMB caused by mivacurium is easily antagonised with neostigmine, or antagonism is not required. ${ }^{3}$ Unfortunately, mivacurium is expensive, especially when compared with pancuronium.

There exists a marked synergism of action when mivacurium is preceded by pancuronium, and NMB is very much prolonged. ${ }^{4}$ A pronounced synergism also exists between mivacurium and pancuronium when they are given simultaneously, but, surprisingly, the spontaneous recovery profile of this combination of mivacurium and pancuronium resembles that of intermediate-acting NMBAs. ${ }^{5}$ However, the hourly maintenance requirements of a combination of mivacurium and pancuronium have not previously been studied.

By giving mivacurium simultaneously with pancuronium, it may be possible to save some cost during maintenance of anaesthesia and still have an easily reversed NMB at the end of operation. This study was designed to evaluate the interaction between mivacurium and pancuronium by constructing doseresponse curves for them and their combination (cMP), and by determining the hourly maintenance requirements and recovery profile of $\mathrm{cMP}$.

\section{Methods}

After local ethics committee approval and written informed consent, we studied 70 ASA physical class III patients aged 17-50 yr. The patients were not taking any medication or suffering from any disease known to affect neuromuscular transmission, and all were within $30 \%$ of their ideal body weight. Premedication was comprised of $15 \mathrm{mg}$ midazolam $p o$. General anaesthesia was induced with $2-2.5 \mathrm{mg} \cdot \mathrm{kg}^{-1}$ propofol, $20 \mu \mathrm{g} \cdot \mathrm{kg}^{-1}$ alfentanil and $\mathrm{N}_{2} \mathrm{O}: \mathrm{O}_{2} 2: 1$, and was maintained with $\mathrm{N}_{2} \mathrm{O}$ in $\mathrm{O}_{2}$ and continuous infusions of 5-12 mg. $\mathrm{kg}^{-1} \cdot \mathrm{hr}^{-1}$ propofol and alfentanil up to $50 \mu \mathrm{g} \cdot \mathrm{kg}^{-1} \cdot \mathrm{hr}^{-1}$. The end-tidal $\mathrm{CO}_{2}$ was kept at $38-42 \mathrm{mmHg}$.

To monitor NMB, supramaximal $2 \mathrm{~Hz}$ train-of-four stimuli (TOF) were given every $20 \mathrm{sec}$ with a pulse width of $100 \mu \mathrm{sec}\left(\right.$ Relaxograph ${ }^{\mathrm{TM}}$, Datex, Finland). The two stimulating electrodes were positioned over the ulnar nerve, the recording electrode over the adductor pollicis muscle, the indifferent electrode on the volar surface on the base of the forefinger and the ground electrode between the stimulating and the recording electrodes. The forearm was attached to a dorsal splint to maintain immobility. Palmar skin temperature was maintained at $>33^{\circ} \mathrm{C}$. When needed, the upper extremities were covered by warm blankets. The neuromuscular function monitor was calibrated following induction of anaesthesia and before administration of NMBAs. The calibration was repeated until unchanged responses were monitored for three min. All NMBAs were injected in $<5 \mathrm{sec}$ into a freely running $i v$ line.

The first 50 patients were randomised into two groups to receive either mivacurium or pancuronium. Group $M$ patients $(\mathrm{n}=30)$ received, randomly, a single bolus dose of mivacurium 50,65 or $80 \mu \mathrm{g} \cdot \mathrm{kg}^{-1}$ (10 patients for each dose) to establish a single-dose dose-response curve for mivacurium. ${ }^{6}$ After the maximal response to the first dose of mivacurium, patients were given an additional bolus dose of $100 \mu \mathrm{g} \cdot \mathrm{kg}^{-1}$. Thereafter, additional bolus doses of $50 \mathrm{\mu g} \cdot \mathrm{kg}^{-1}$ mivacurium were given to determine hourly maintenance requirements of mivacurium to maintain 85-95\% NMB. Group P patients $(n=20)$ received incremental doses of pancuronium to establish individual cumulative-dose dose-response curves for pancuronium, followed by maintenance doses of pancuronium of $1 / 5$ of the individual $E_{95}$ every time the $T_{1}$ (first EMG response in the train-of-four series of responses) recovered to $10 \%$ of baseline. The first dose of pancuronium was $25 \mu \mathrm{g} \cdot \mathrm{kg}^{-1}$, followed by $15 \mu \mathrm{g} \cdot \mathrm{kg}^{-1}$ and a final individual dose to establish $95 \% \mathrm{NMB}$ ?

The remaining 20 patients (group cMP) received incremental doses of cMP in a mg:mg ratio of 2:1 to establish individual dose-response curves for cMP. The first and the second doses of mivacurium and pancuronium were 15 and $10 \mu \mathrm{g} \cdot \mathrm{kg}^{-1}$, and 7.5 and $5 \mu \mathrm{g} \cdot \mathrm{kg}^{-1}$, respectively. Thereafter, a final individual dose of cMP was calculated to establish 95\% NMB.? Then, patients were randomised to receive maintenance doses of cMP in a $\mathrm{mg}: \mathrm{mg}$ ratio of either $2: 1$ or 20:1, 10 patients for each dose, were given in order to determine the maintenance requirement of $\mathrm{cMP}$ to maintain a $85-95 \%$ NMB. At the end of the operation of these 20 patients, $35 \mu \mathrm{g} \cdot \mathrm{kg}^{-1}$ neostigmine together with $0.4 \mathrm{mg}$ glycopyrrolate was given when $T_{1}$ had returned to $10 \%$ of the baseline. Thereafter, we measured the time to a TOF-ratio of 0.70 .

A standard least squares linear regression analysis of log-doses and probit-responses was used to determine individual dose-response curves for the muscle relaxants. ${ }^{6}$ We used analysis of variance (ANOVA) for statistical comparisons. If the ANOVA showed significant differences between the groups, the following individual group comparisons were done by using Scheffe F-test. When analysing the maintenance requirements, 
possible synergism between mivacurium and pancuronium was also evaluated by using an isobologram. ${ }^{8}$ Values are expressed as mean $\pm S D$. All randomisation was done by drawing lots. A $P$ value $<0.05$ was considered statistically significant.

\section{Results}

The study groups did not differ in age or body weight (Table I). Dose-response and maintenance data for the parent agents and their combinations are presented in Table II and in Figures 1 and 2. Due to great variation of neuromuscular response, the target neuromuscular block (NMB) could be maintained in only eight patients in group $M$ for whom the hourly maintenance requirements of mivacurium were calculated. There was little deviation from linearity in regression of log-doses and probit-responses $\left(r^{2}=0.9944 \pm\right.$ 0.0076 ). The slopes of the individual dose-response curves were slightly steeper for cMP than for the parent agents $(P<0.05)$. If one $\mathrm{ED}_{95}$ of a parent agent is taken as one dose-equivalent, then $\mathrm{ED}_{95}$ of $\mathrm{cMP} 2: 1$ was $0.55 \pm 0.13$ dose-equivalents $(P=0.0001$ compared with the parent agents) (Table II).

When cMP was administered in a dose-ratio of 2:1, $60 \%$ of normal maintenance requirement of pancuronium reduced the requirement of mivacurium by $>90 \%$

TABLE I Patient characteristics. Group $\mathbf{M}=$ mivacurium, group $P=$ pancuronium and group $c M P=$ combinations of mivacurium and pancuronium.

\begin{tabular}{lllll}
\hline Group & $n$ & Age $(y r)$ & Weight $(\mathrm{kg})$ & Height $(\mathrm{cm})$ \\
\hline Group M & 30 & $36.7 \pm 9.7$ & $73.9 \pm 11.6$ & $169 \pm 10$ \\
Group P & 20 & $38.3 \pm 10.4$ & $67.9 \pm 10.1$ & $168 \pm 8$ \\
Group cMP & 20 & $35.3 \pm 9.8$ & $71.5 \pm 9.1$ & $168 \pm 9$ \\
P-value & NS & NS & NS & \\
\hline
\end{tabular}

Values are mean $\pm S D$.
$(P<0.0001)$. If $\mathrm{cMP}$ was administered in a dose-ratio of $20: 1$, then $20 \%$ of normal maintenance requirement of pancuronium reduced the requirement of mivacurium by $>70 \%(P<0.0001)$ (Figure 1$)$. In group cMP, $35 \mu \mathrm{g} \cdot \mathrm{kg}^{-1}$ neostigmine given at $\mathrm{T}_{1} 10 \%$ recovery achieved a TOF ratio of 0.70 in $9.5 \pm 3.9 \mathrm{~min}$.

\section{Discussion}

We established a single dose dose-response curve for mivacurium because mivacurium is so short-acting. ${ }^{3,9}$ The cumulative dose technique has been shown to be valid in case of pancuronium. ${ }^{6}$ The $\mathrm{ED}_{95}$ values for

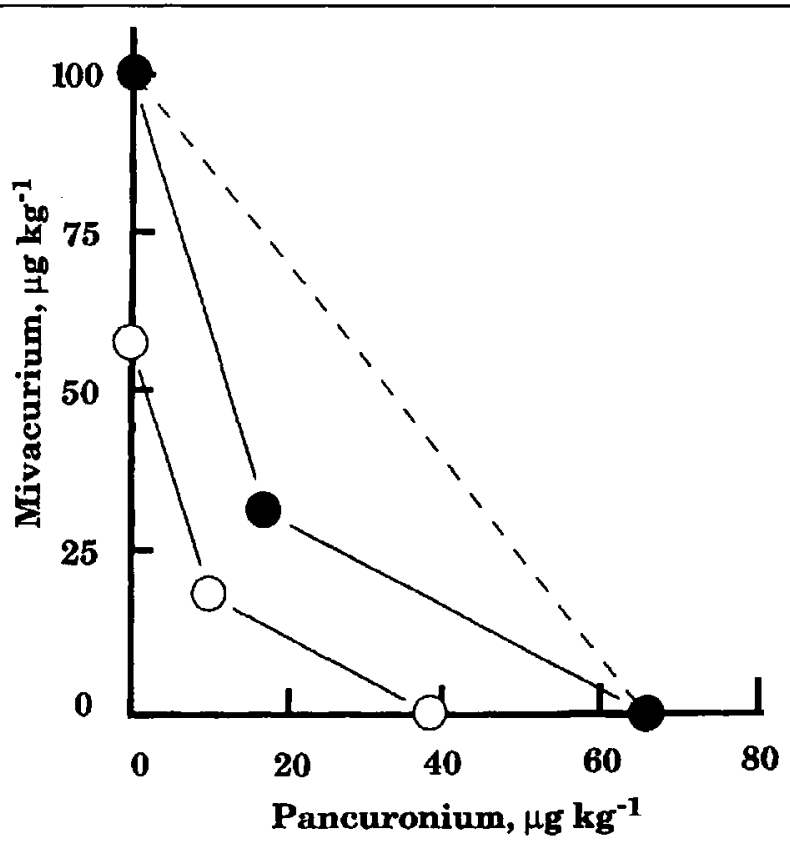

FIGURE 1 The $\mathrm{ED}_{50}$ (open circles) and $\mathrm{ED}_{95}$ (closed circles) values for mivacurium, pancuronium and their combination (cMP). The potency of the cMP is greater than if only additivity existed between mivacurium and pancuronium.

TABLE II Dose-response and maintenance data for mivacurium $(n=30)$, pancuronium $(n=20)$ and their combination $(c M P, n=20)$. Maintenance data for cMP was determined in two dose-ratios $(2: 1(n=10)$ or 20:1 $(n=10)$ in mg:mg basis). ED50 and ED95 = doses needed to achieve 50 or $95 \%$ neuromuscular block.

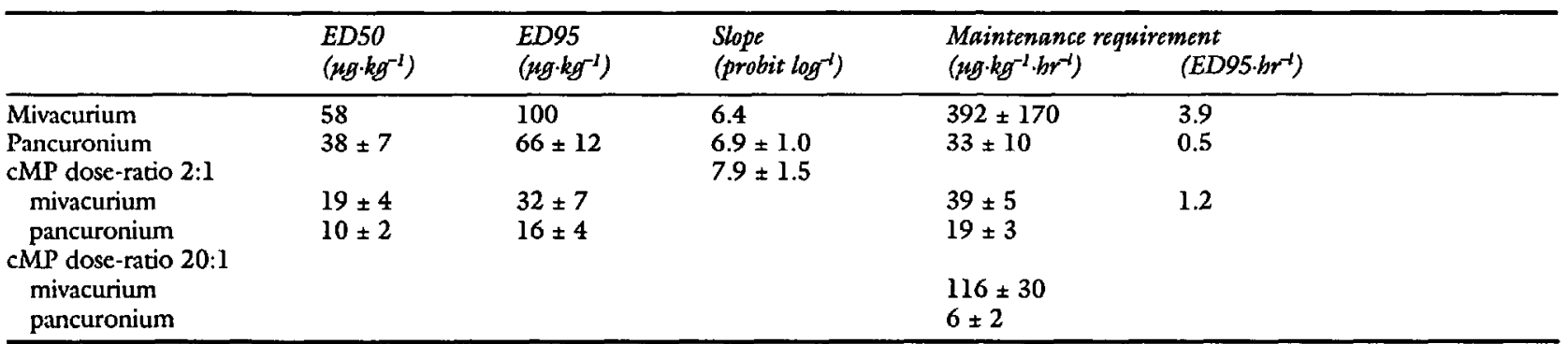

Values are mean \pm SD. 


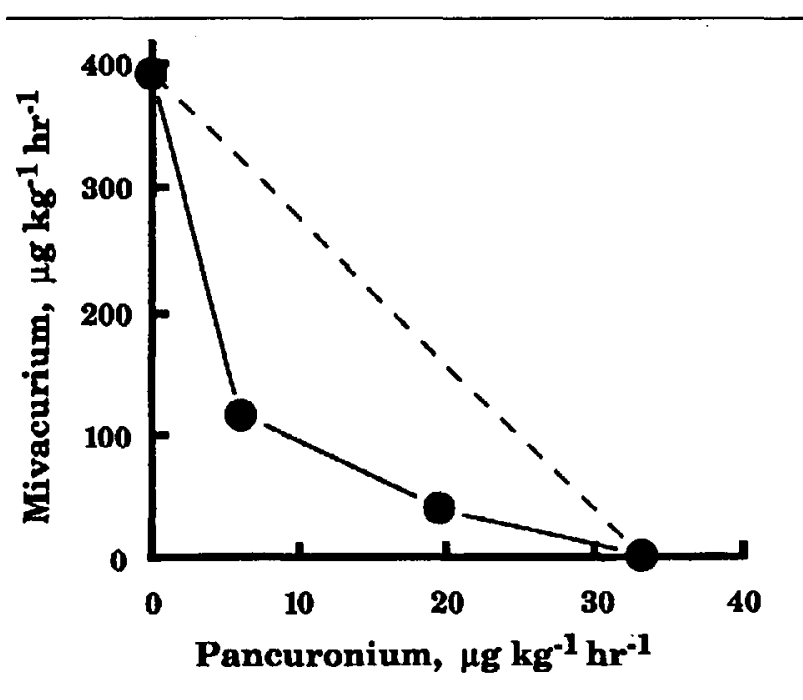

FIGURE 2 Potentiation of effects between mivacurium and pancuronium during maintenance of neuromuscular block. The potencies of both cMPs were greater than if only additivity existed between mivacurium and pancuronium.

mivacurium and pancuronium were about the same as those previously published. ${ }^{3-6}$ The cumulative dose technique was adequate in the case of cMP because the slope of the dose-response curve for cMP was steeper than the slope of the dose-response curve for pancuronium. This indicates that insignificant amounts of mivacurium and pancuronium were metabolised during the construction of the cumulative dose dose-response curves for $\mathrm{cMP} .^{10}$

Our results support the postulated synergism between mivacurium and pancuronium and show that pancuronium has profound effects on the NMB established by mivacurium. ${ }^{4,5,11}$ The cMP in a dose-ratio of 2:1 (in $\mathrm{mg}: \mathrm{mg}$ basis) was 1.8 times as potent as one parent agent (Figure 1). Maintenance requirements of cMP were $<50 \%$ of that of one parent agent (Figure 2). Brandom et al. found that a priming dose of pancuronium prolonged mivacurium-induced neuromuscular block by $100 \% .^{11}$

The average hourly requirement of mivacurium was $392 \mu \mathrm{g} \cdot \mathrm{kg}^{-1} \cdot \mathrm{hr}^{-1}$. When we administered $\mathrm{cMP}$ in a dose-ratio of $2: 1$, the requirement of mivacurium was $39 \mu \mathrm{g} \cdot \mathrm{kg}^{-1} \cdot \mathrm{hr}^{-1}$ together with pancuronium $19 \mu \mathrm{g} \cdot \mathrm{kg}^{-1} \cdot \mathrm{hr}^{-1}$. This demonstrated that $60 \%$ of normal maintenance dose of pancuronium reduced the requirements of mivacurium by $90 \%$. An interaction between mivacurium and pancuronium became even clearer when we analysed patients who received mivacurium and pancuronium in a dose-ratio of 20:1. In these patients, a small dose of pancuronium of $6 \mu \mathrm{g} \cdot \mathrm{kg}^{-1} \cdot \mathrm{hr}^{-1}$ reduced the requirement of mivacurium by $70 \%$ of the normal.
The hourly maintenance requirements for short-, intermediate- and long-acting NMBAs are about 5.0, 2.0 and 0.5 times their respective $E D_{95}$ doses. ${ }^{12}$ In this study, these requirements for mivacurium and pancuronium were 3.9 and 0.5 times their $\mathrm{ED}_{95}$ values, respectively, when administered alone. The hourly maintenance requirement of $\mathrm{cMP}$ was 1.2 times $\mathrm{ED}_{95}$ $\mathrm{hr}^{-1}$. This was between those of pancuronium and intermediate-acting NMBAs when used alone. We also found that it was easy to antagonise the NMB produced by $\mathrm{cMP}$. Many investigators have documented prolonged NMB after long-acting neuromuscular relaxants despite the administration of reversal drugs. ${ }^{2}$ In the cMP group, no prolonged NMB was found after reversal with neostigmine, probably because the recovery profile of $\mathrm{CMP}$ resembles that of intermediate-acting NMBAs. ${ }^{13-14}$

The observed synergism can be explained by our theory of $\alpha$-subunit binding. ${ }^{8}$ Binding by a competitive antagonist (muscle relaxant) to one of the two $\alpha$-subunits on the postsynaptic acetylcholine receptor is sufficient to block activation of the receptor. Accordingly, there may be a decreased interaction of a second competitive muscle relaxant with the other $\alpha$-subunit if a structurally different drug already occupies one $\alpha$-subunit. $^{8,15}$ Mivacurium and pancuronium are structurally different. $^{3-4}$ Consequently, more acetylcholine receptors become occupied when the $\mathrm{CMP}$ is used than by one parent agent and the ensuing neuromuscular block may become greater.

Clinically effective doses of pancuronium may slightly reduce the cholinesterase activity and thereby prolong the effect of mivacurium. ${ }^{16}$ However, in a dose-ratio of $20: 1$, a minimal dose of pancuronium decreased requirement of mivacurium by $70 \%$ which can not be explained by changes in cholinesterase activity.

The results demonstrated that $\mathrm{cMP}$ was a synergistic mixture and resulted in reduction of the dose required to establish NMB. More importantly, this combination had very strong supra-additive effects during maintenance of NMB. This may be a cheaper method of inducing and maintaining NMB because pancuronium is less expensive than mivacurium and reduces the requirements of mivacurium. The prices in Canada for mivacurium and pancuronium are $\$ 0.50$ and $\$ 0.81 \mathrm{mg}^{-1}$, respectively. For example, an $\mathrm{ED}_{95}$ dose of mivacurium for a $70-\mathrm{kg}$ patient costs $\$ 3.50$ and hourly maintenance of $\mathrm{NMB}$ with mivacurium costs $\$ 13.72$. When using a cMP 2:1, these costs are on average $\$ 2.02$ and 2.44 , respectively. These are only $26 \%$ of the costs of mivacurium.

In conclusion, we found that a clear synergistic effect existed between mivacurium and pancuronium 
when given simultaneously. This combination was near intermediate-acting and NMB was easily reversed with neostigmine. Therefore, cMP may be a clinically useful combination of NMBAs.

\section{References}

1 Bevan DR, Smith CE, Donati F. Postoperative neuromuscular blockade: a comparison between atracurium, vecuronium, and pancuronium. Anesthesiology 1988; 69: 272-6.

2 Viby-Mogensen J, Jorgensen BC, Ørding $H$. Residual curarization in the recovery room. Anesthesiology 1979; 50: 539-41.

3 Savarese J, Ali HH, Basta SJ, et al. The clinical neuromuscular pharmacology of mivacurium chloride (BW B109OU). Anesthesiology 1988; 68: 723-32.

4 Erkola $O$, Rautoma P, Meretoja OA. Mivacurium when preceded by pancuronium becomes a long-acting muscle relaxant. Anesthesiology 1996; 84: 562-5.

5 Rautoma P, Erkola O, Meretoja OA. Synergism between mivacurium and pancuronium in adults. Acta Anaesthesiol Scand 1995; 39: 733-7.

6 Donlon JV Jr, Savarese JJ, Ali HH, Teplik RS. Human dose-response curves for neuromuscular blocking drugs: a comparison of two methods of construction and analysis. Anesthesiology 1980; 53: 161-6.

7 Meretoja OA, Wirtavuori K. Two-dose technique to create an individual dose-response curve for atracurium. Anesthesiology 1989; 70: 732-6.

8 Meretoja OA, Brandom BW, Taivainen T, Jalkanen $L$. Synergism between atracurium and vecuronium in children. Br J Anaesth 1993; 71: 440-2.

9 Ali HH, Savarese J, Embree PB, et al. Clinical pharmacology of mivacurium chloride (BW B109OU) infusion: comparison with vecuronium and atracurium. Br J Anaesth 1988; 61: 541-6.

10 Brandom $B W$, Meretoja $O A$. Dose-response calculations revisited (Letter). Anesth Analg 1994; 78: 608-9.

11 Brandom BW, Meretoja OA, Taivainen T, Wirtavuori $K$. Accelerated onset and delayed recovery of neuromuscular block induced by mivacurium preceded by pancuronium in children. Anesth Analg 1993; 76: 998-1003.

12 Meretoja $O A$. Neuromuscular blocking agents in paediatric patients: influence of age on the response. Anesth Intensive Care 1990; 18: 440-8.

13 Whalley DG, Lewis B, Bedocs NM. Recovery of neuromuscular function after atracurium and pancuronium maintenancé of pancuronium block. Can J Anaesth 1994; 41: 31-5.

14 Stinson LW Jr, Lanier WL, Lennon RL. Train-of-four recovery after pharmacologic antagonism of pancuronium-, pipecuronium-, and doxacurium-induced neuromuscular block in anaesthetized humans. Acta Anaesthesiol Scand 1995; 23: 406-10.

15 Waud $B E$, Waud $D R$. Interaction among agents that block end-plate depolarization competitively. Anesthesiology 1985; 63: 4-15.

16 Stovner J, Oftedal N, Holmboe J. The inhibition of cholinesterases by pancuronium. $\mathrm{Br} \mathrm{J}$ Anaesth 1975; 47: 949-54. 